\title{
Political Ecology of Cholera: Orissa and Colonial Sanitary Discourse
}

\author{
Chandi Prasad Nanda*
}

Department of History, Ravenshaw University, Cuttack.

(Received 26 August 2019; revised 28 February 2020)

\begin{abstract}
The essay pertains to the study of disease and medicine and the extent of its influence on the colonial policy and the colonizing process in the context of Orissa. It explores the linkages between medical knowledge and the colonial power drawing resources from medical archives. It seeks to illustrate the complexities associated with the processes of colonial medical interventions in combating cholera epidemic and the popular responses to it during 19th and 20th century Orissa. The colonial strategy provides an understanding of how a political reading of the disease took precedence over its overt medical implications. In the process it conduced to reinforce the very basis of the "pathological province" about which the colonial state had remained so critical.
\end{abstract}

Key words: Cholera, Contagion, Epidemic, Jogini, Kalishi, Ola-utha, Pathology, Pilgrimage, Public Health, Sanitary.

\section{Introduction}

The present essay seeks to illustrate the complexities associated with the processes of colonial medical interventions to combat the cholera epidemic and popular responses to it in Orissa during 19th and 20th century. In these processes, it seeks to configure the shaping of a "pathological" province as claimed by the modern projects on public health. This study also delineates the disease in relation to its extent of influence, both on the colonial policy, its colonizing process and the colonized masses.

\section{The world of disorder}

Mortality from cholera along with smallpox, considered two scourges of humanity remained alarmingly largest in

DOI: 10.16943/ijhs/2020/v55i1/152343

*Email: chandinanda@gmail.com the districts of Orissa in Bengal Presidency in the late 19th century with incidence of cholera mostly seen amongst the poorer classes of people. ${ }^{1}$ As an abiding social reality, cholera was reflected in the literatures of 19th century Orissa. Rebati considered as the first Oriya modern short story (1898) and the Oriya novel Shasti (1946) offer chilling reminders to the dread and devastation caused by cholera during colonial period (Behera and Dash 2009, p. 48; Mohanty 1994, pp. 16-17). ${ }^{2}$

\footnotetext{
${ }^{1}$ Utkal Dipika (hereafter UD), 30 August 1884; UD, 22 July, 1876.

${ }^{2}$ Oriya literature illuminates the trace of cholera as a ferocious disease since 19th century. Fakir Mohan Senapati (considered as the father of modern Oriya literature) in his story of a country girl narrates the tragic death of everyone in a family- both father and mother and their only daughter Rebati due to cholera. Similarly, another story Shasti (1946) by Kanhu Charan Mohanty offers a gripping account of the aftermath of famine and pestilence during the years 1866 and 1870. It is against this setting, the author narrates the pathetic tale of a wealthy man of a village who volunteers to open chutter (public kitchen) as cholera strikes but in the process of feeding the kangalees
} 
Before the commencement of steamer and rail communication with Bengal, the disease often struck through the grand trunk road with the stream of pilgrims using the route to visit Puri (O'Malley 1911). The disease was quite intense in Balasore during the famines of 1853 and 1866 and people were reported to have fled the houses leaving the dead and dying behind. One comes across reference to the greatest mortality occurring in the unnochutter (public kitchen distributing boiled rice) in Puri during the 1866 Orissa famine in which the kangalees (famine stricken destitute) suffered the most (Smith 1868, part II, pp. 71-72). Originating from southern Orissa, cholera spread to Puri and the epidemic took a serious turn in March 1866 with greater flow of pilgrims during Dola festival. People died in great numbers in the epidemic and the streets of Puri would witness 10 to 15 corpses every day. The corpses would lie on road decomposed for a long time as there was no provision of shifting the bodies to cremation ground. Later on, contractual sweepers were engaged by the municipal administration with four palanquins to remove the corpses to the cremation ground. But as the number of corpses increased every day, the sweepers would throw these dead bodies into the cremation ground instead of burning them. The putrid stench of the decomposed bodies at the cremation ground was intensely repulsive for anyone to visit the place. It was believed that the dogs and jackal would also stay off from the dead bodies of the destitute because of the odour. The fear of modern hospital and loss of castes on being touched by lower caste sweepers often made the cholera patients refuse to be shifted to hospitals. They would prefer to die on the roads (Dash 2011, p.109). Similarly, during 1889 famine, occurrence of first death of cholera and its spread with appalling rapidity was caused by persons who fled from the epidemic in the adjoining states of the central provinces. This led to panic stricken new comers deserting Cuttack town as residents shut themselves up in the houses. All channels of communications stood snapped in the interior (O'Malley 1908).

Cholera entailed intense suffering for people in the gadjat (feudatory) states of Orissa with high degree of mortality. The Rājā of Hindol died of cholera in 1877 (Utkal Dipika, 28 July 1877). The disease evidently assumed epidemic form in view of the attempts by the Rājās to either

( hungry destitute) and clearing corpses, his entire family except his daughter-in-law get perished by the disease. desert people for their own safety or shut themselves inside the palace when the disease struck. To add to the peoples' woes, all channels of communication with the mughalbandi (British ruled) areas were snapped when the disease struck, as people of the latter would not visit these areas even for trading purposes due to panic. Utkal Dipika (8 June 1872) strongly criticized the apathy of the king for almost doing nothing to mitigate the suffering of people, at a time when methods of treatment were available.

It is worth noting here that a temporary central famine hospital opened at Nimapara in Puri in May 1920 registered $24.7 \%$ death among its debilitated population mostly from dysentery. ${ }^{3}$ As late as 1943, the reasons for high epidemic curve of cholera and other gastrointestinal disorders in Orissa were attributed to cyclone in coastal Orissa, shortage of food as well as congregation of unprecedented number of pilgrims in Puri following the rumour that Lord Jagannath would be washed away after the ratha jātrā festival of $1943 .^{4}$

\section{Coping with the wrath of cholera goddess}

Epidemic cholera was commonly referred to as badi, haija, ola-utha and viśucika in popular parlance in Oriya. ${ }^{5}$ The reference to cholera-like diarrheal disease known as viśucika is found in ancient Indian medical text, Suśruta Samihtā of Suśruta. Caitannya Caritāmrta, the celebrated text by the Vaisnnavas also referred to the incidence of this disease in Puri in 1512 (Sen 2012, p. 348). As the disease is characterized by sudden and violent acts of defecation, vomiting and purging, it is called ola-utha (ola means to void excrement downward from the bow-

${ }^{3}$ OR. Doc., 28568, Notes on the Annual Returns of the Hospitals and Dispensaries in Bihar and Orissa, 1920, Report by Inspector General of Civil Hospitals, Bihar and Orissa, H. Austen Smith; 3 March, 1921, Patna.

${ }^{4}$ Lt. Col. B. N. Hajra, M .R. C. P. (London), Director of Health and Inspector-General of Prisons, Annual Public Health Report of the Province of Orissa, 1943, Odisha State Archives, Bhubaneswar (hereafter, OSA).

${ }^{5}$ Cholera was popularly referred to as badi by the rural folk of Orissa till about second half of 20th century. The dread of the disease with its obvious association of death was so pervasive in popular perception that, it often came to be used as a slang with derogatory and cursing motif such as badipada (one who suffers from cholera and dies on the way) or badikhia (who gets death being attacked by the disease). 
els through the anus and utha meaning the liquid substance within the bowel undergoing an upward movement through the mouth). The virulence, ferocity and lack of effective cure for the disease led to the widespread popular belief about the disease as divinely ordained through its identification with goddess Ola debi thereby undermining faith on its cure through modern medicine (Sen 2012, pp. 50-51; McNamara 1870, pp. 45-98). Utkal Dipika (26 March 1870) provides an interesting account of history of cholera in pre-1817 Calcutta by McNamara, a surgeon at Calcutta's Ophthalmic Hospital. ${ }^{6}$

In view of the religious significance of the disease, soliciting divine help based on nagara sankïirtana, (taking out religious procession around the village and town), organizing harikkatha or chabisiprahari (religious congregation marked by chanting the name of Lord Hari) or public reading of Bhagavata, (the sacred Oriya text) became popular recourse for cure during cholera epidemic (Behera and Dash 2009, p. 15). ${ }^{7}$ The faiths in such divine cures as

\footnotetext{
${ }^{6} \mathrm{McNamara}$ related the genesis of the term Ola-ota, used by the natives to describe cholera to an incident of early eighteenth century involving a wandering old woman in the forests who came across a stone that was worshipped as the goddess for Ola-ota, called Ola-bibi. The importance of worshipping the goddess Ola-bibi who used to attract worshippers from distant places illuminates that the disease Olaota must have caused too much of health problems and mortality for the inhabitants of Calcutta and Bengal in the early eighteenth century. Probably around 1720, an English merchant, Duncan gave Rs 4000/for a temple to the goddess Ola-bibi. In 1750, Duncan again donated Rs 6000/- for the erection of a second temple to the goddess Ola-bibi in Calcutta. The old rude stone was transferred to the new abode and a somewhat elaborate idol was constructed. This may reveal that the mortality rate among the Europeans might also have been very high, so the fund came from a European for the erection of two temples for goddess Ola-bibi.

${ }^{7}$ Fakir Mohan Senapati's famous novel Chhaman Athaguntha (Six Acres and a Third) (1897) refers to goddess Budhi Mangala, the presiding deity of an obscure village of Gobindpur in coastal Orissa as Badisangarani Narayani (the deity Narayani, slayer of Badi or cholera). Apart from the glory of the deity which lay in her miraculous power to turn a barren woman a mother, the belligerent goddess, it was widely believed, could also leave a trail of death by spreading cholera. Senapati describes how the deity was worshipped with fanfare by villagers during periods of cholera epidemic. He adds that when conciliated appropriately through worship, the goddess could not take more than 50 to 100 lives and left the village. Senapati interestingly draws the attention of the reader to hopeless efforts of so many doctors who were engaged to treat people during incidents of Bengal epidemic fever and Bombay plague. He uses this context to invite reader to ponder about modernity and its gifts of science and medicine which rubbish popular practice of finding cure through worship of goddess.
}

a form of psychopathic treatment were geared to generate psychological confidence and mental strength to endure the disease (UD 30 August 1879).

The disease in popular perception remained linked to the acts of a jogini (a woman with haggard face or deportment and who could eat human beings raw). The joginis were to be propitiated to avert the scourge of cholera. The village deities were believed to have control over the joginis and thus had to be worshipped by people to seek protection from these capricious adversaries in the event of outbreak of the epidemic. A kalishi (spirit medium) or the woman disciple of the deity often get possessed by the spirit of the latter and show up before a village crowd pronouncing inspired oracles. She becomes instrumental in driving out the joginis from the specified area of her operation. $^{8}$

Another interesting practice to ward off cholera was to entice the goddess of cholera to leave a village through offerings of food and sacrificial victims. For instance, following a divine command supposedly issued by goddess Sarala, people would keep earthen pots containing rice, mango, vegetables and a piece of either copper or silver metal at the backyard of their houses to be subsequently removed to the village junction in the rural tracts of coastal Orissa (UD, 10 May 1873). The people of the adjacent villages would then transfer these pots to the borders of next village till these pots finally reached the place of goddess Bimala in Puri. Known as handibuha (circulation of earthenware pot), the pots would thus be transferred to Puri in a span of few days without the supervision of anybody. More so, nobody would dare to steal anything from the pots for fear of dying from cholera instantly. Even pathāns (Muslims) would abide by such divine command of Hindu goddess and would not dare to take away anything from these pots. The belief that those who would not participate in the ritual by subscrib-

${ }^{8} U D$, 15 Sept. 1877. Reporting an incident of kalishi ritual in Cuttack town Utkal Dipika, observed how the people of a specific locality brought a lady who was possessed by goddess and based on her advice agreed to accept two of her sisters as kalishis. As the three sisters danced to the tunes of the drums at the door step of a cholera patient, another lady of a nearby locality, seemingly possessed by the spirit of the goddess came running to these three ladies and hugged them while reminding them that she was the village deity of that area. She further threatened that many more people in the area would be killed in cholera if people ignored to respect her. Terribly scared, the spectators rushed to apologize before her with folded hand, pleading to forgive them for their blunder of not recognizing them. 
ing pots, or people of the village, where the pots would remain unmoved and those who would steal from such pots would incur the wrath of the jogini. This acted as a strong deterrent to keep the pots moving on to their intended destination. Such rites have been seen as ploys to divert the baleful influence of the goddess to safe distance (Arnold 1993, p. 176). It is worth noting here that similar circulation of ghadā (earthen pots) originating from Gwalior and passing through more than ninety villages along the borders of UP, Madhya Pradesh and Rajasthan to ward off epidemic cholera was reported in 1860 (Arnold 1993, p. 177).

Though official reporting about the practice of handibuha in Orissa is lacking, it may still have been somewhat reminiscent of the [in] famous circulation of chapatis of 1857 for the colonial order. However, unlike chapatis which did encode a symbolic message to mobilise against the enemy, earthenware pot was a device like chapatis intended to circulate and offer protection against cholera epidemic that ravaged the coastal region. Ranjit Guha argues that such practice were symbolic of a "collective sense of anxiety at the nature of British rule and the anticipation of some impending catastrophe" (Guha 1999, pp. 238-46). Despite its lack of anti-colonial symbolism, such acts of propitiation of disease through handibuha for the colonial order implied contexts for reinforcing rural solidarity and lateral communications, in an area which remained off the colonial control. In other words, such networks of local solidarity born out of collective religious acts were likely to have been viewed with concern and alarm.

The colonisation of Indian society bred complex perception about the disease and its cure by the indigenous people. The Saura tribe of Orissa had the tradition of worshipping a god - Sahibosum (Sahib-white man). Perhaps the white European officials like a touring forest guard or a policeman was identified by the Saura tribe as the one carrying cholera (Elwin 1955, pp. 180-181, 490, 510). They would carve a wooden image in his honour at the outskirts of their villages and please him through sacrifice to divert the gaze of the god from their village. Similarly, Ringesum, the god of wind for the Sauras was identified with diseases like cholera and hernia (Elwin, 1955, pp. 121, 397). Such conceptualization of the disease points to anti-colonial dimension.

The colonial government including many of its mis- sionaries, doctors and sanitary experts lampooned the observance of rites, rituals and worships of deities as symbol of primitivism and irrationality. However, the popular faith sought to interrogate the legitimacy of the colonizer's authority, therapeutics, and faith. It was obvious that the colonialists tended to view such religious activities with suspicion as it had the potential to cause disorder in the area of trade, revenue, agriculture and administration. Under the circumstances, it was more of a concern for political and financial security that characterized the British response in dealing firmly with such instances of religious rites in different regions of India rather than mere medical apprehensions about the epidemic (Arnold 1993, pp. 173-176). ${ }^{9}$ Such measures were unavoidable to obviate the possibility of popular disillusionment threatening the order of the empire.

\section{Imaging cholera through orientalist lens}

The medical discourse about cholera till late 19th century was marked by persisting uncertainty about its cause and mode of transmission. On the whole, the predilection for a non-contagionist perspective of the disease was evident. Such a perspective palpably undermined the possibility of state interventionism against the disease. The issue of pilgrimage control was reviewed with caution after Queen's post-1857 proclamation of non-interference with the religious privileges of the native people. It was deemed both impractical and undesirable to interfere with this religious privilege. It was believed that popular appeal for evils like pilgrimage would wither away with growth of western education and appreciation of values of sanitation and hygiene by people (Arnold 1993, p. 190). The colonial practice therefore was a policy of tightening the prevailing sanitary surveillance system at fairs and pilgrimage sites than resorting to a policy of general prohibition of pilgrimage. But such cautious nature of state interventionism even came under question as it could entail enormous expenses on public health, a choice not very friendly to colonial regime. The sentiment against sanitary surveillance of quarantine and cordons was exhibited by the colonial government and its metropolitan su-

${ }^{9}$ Arnold delineates a critical account on the response of the colonial state to cholera across different regions of India. 
perior in London as well. They equally articulated their opposition to the proceedings of Constantinople Sanitary Conference (1866) which harped on the validity of a contagionist perspective of cholera. Besides, survey on the disease with pilgrims visiting Hardwar had pointed to the contagionist basis of the disease which seemed to have insignificant impact on Indian medical discourse. Such opposition was in fact, ideologically rooted in its belief that quarantine would help inflict continental despotism and adversely impact free trade and commerce and free movement of travellers. It was also believed that quarantine while entailing a lot of hardship wouldn't provide any effective remedy against the disease (Arnold 1993, p. 191).

The standard explanations about cholera epidemic remained woven around climatic aberrations of India linked with fluctuations in temperature or sudden, heavy rain or miasmatic factors resulting out of human filth, crowded habitations or rotting vegetation. The atmospheric explanations quoted in the work of James Johnson, a Royal Navy Surgeon had seminal effect in Indian medical circles though its appeal had considerably declined in European medical circles long before. ${ }^{10} \mathrm{He}$ perceived environment as an accessory factor than specifically being the cause of a contagious disease based on person to person contact (Johnson 1813, p. 192).

The robust conviction against the contagionist perspective however was strikingly shaped by the dogged determination of officials like J. M. Cunningham, the Indian sanitary commissioner (1868-1884) and J. L. Bryden, statistical officer to Sanitary Commissioner of India. Seeing India as home to cholera, Cunningham attributed its prevalence to aerial miasma or the specific condition of air or soil, or of both combined (Arnold 1993, pp.192-193). Denouncing contagion aspect of the disease, he remained a rabid critic of pilgrim theory arguing that pilgrim succumbed to cholera due to their fatigue and privations. He scoffed at the idea of quarantines or sanitary cordons in order to combat cholera viewing that it would be no more logical or effectual than to post a line of sentries to stop the monsoon. Such sanitary discourse enthusiastically seemed to have been approved by the state formally reposing its trust on a policy of laissez-faire alongside its reluctance to spend more than necessary for its own security

\footnotetext{
${ }^{10}$ Johnson, James, 1813. The Influence of Tropical Climates, More Especially the Climate of India, on European Constitutions, London: Stockdale cited in David Arnold, op.cit.p. 333.
}

on public health. J. L. Bryden's statistical investigation further sought to stress on the metrological significance of the disease while ruling out the factors of human communication including his refutation of John Snow's theory of cholera as a waterborne disease (Arnold 1993, p. 193). His views were endorsed by subsequent medical and statistical research mapping equation between cholera and special climatic conditions. Later, the discovery of cholera bacillus by Robert Koch, a German bacteriologist was not officially acknowledged by the British medical order on account of patriotic pride and professional rivalry. So much so that, a subsequent cholera commission tasked to verify Koch's finding observed that bacillus located by the latter could not be held specifically responsible for cholera as the bacillus was innocuous to the utter relief of noncontagionist exponents. Though bacillus theory emerged as the new medical mantra for cholera after Koch's discovery, the hegemonic contention lay in support of the noncontagionist character on grounds of commercial and political considerations. This insight was illuminated by Sir Joseph Fayrer, surgeon-general at the India Office Council based in London, who argued that proof of cholera's contagious character would entail irresistible argument for quarantines and tighter international sanitary controls over India's overseas trade (Arnold 1993, p. 194).

A non-contagionist perspective of cholera adopted by the colonial medical world was reinforced by the thought of policy of laissez-faire and non-intervention. This strand of opinion was out of tune with advances made in medical research. The environmentalist discourse sought to conjure an orientalist image of India intrinsically different from Europe in terms of its physical or climatic idiosyncrasies and peculiar needs (Arnold 1993, p. 195). ${ }^{11}$

\footnotetext{
${ }^{11}$ The Orientalist perspective was illuminated in the body of medical research on India during $19^{\text {th }}$ century. The accounts on India's pathogenic climate and landscape scripted by medical commentators and topographers of the period not only differed from the standard understanding of the very theme prevalent as in Europe but also distanced itself from the enchanting narratives on India as a "land of desire" with its "treasures of nature". This view found clearer articulation with medical doctors like John Clark in the 1760s who characterized the Bengal region as "unhealthy and hazardous" which exerted unhealthy impact not only on the body in its physiological and pathological effects but could be seen in the extremity of climate and topography. Further, Charles Curtis's 1802 monograph, An Account of the Diseases of India, as They Appeared in the English Fleet, and in the Naval Hospital at Madras, in 1782 and 1783 demonstrated the unfamiliarity of the Indian environment and its extreme and deleterious effects on the human arguing that "European nosology and definitions" stood as
} 
Such perspective trumpeting idea of climatic eccentricities curiously stood to endorse the views of the contagionist school which saw in the pilgrim hordes of India (as in Hardwar or Puri), the carriers of cholera. In sum, the soil, the environment and the people of India were held guilty for spreading the menace of cholera.

Despite the official favour enjoyed by non-contagionist, the emphasis on issues of good sanitation and clean drinking water were highlighted both by contagionist as well as non-contagionist school. But on the whole, backed by the overriding financial and political constraints, noncontagionism virtually deepened the state's overall engagement with cholera. It was evident in their cautious and piece-meal intervention, under-emphasizing its urgency as a public health problem. However, a perceptible shift occurred around 1890s in favour of contagionism with the official acknowledgement of the theory. It led a more proactive approach on part of official and medical regime to take on cholera. However, the political considerations continued with their lurking presence while contemplating a policy of state interventionism against cholera.

The practice of medical and sanitary techniques against cholera also came to be impacted both by financial and political considerations. The use of saline to restore body fluid of cholera patients largely remained a hospital oriented medical technique having little impact on patients of rural areas who were cut off from medical institutional networks. Similarly, the anti-cholera vaccine developed by bacteriologist, Haffkine in the 1890s had limited receptivity in Indian medical as well as official circles (Arnold 1993, p. 197). The idea of adopting the policy of compulsory inoculation was cautiously viewed in official circles as it had the potential of provoking popular resentment resulting from interference with fairs and festivals. Such perception climaxed with rejection of the policy of compulsory inoculation for pilgrims in1930s on account of rising nationalism coinciding with the call for Civil Disobedience campaign by Indian National Congress. It is thus the abiding political considerations which continued to critically shape the official career of cholera in Indian subcontinent till about 20 th century in varied shapes.

"uncertain or fallacious guides" for medical investigations into Indian diseases.

\section{Colonial order and geography of cholera}

The section seeks to delineate how the colonial establishment portrayed Puri/ Orissa in the larger configuration of cholera. The imageries of Jagannath, Puri and Hinduism featured prominently in the official as well as the medical discussion of the colonial order though the lineage of such discussion can be traced to the missionary polemic of Claudius Buchanan, James Peggs or Reverend J. Buckley beginning with early 19 th century.

Right since the annexation of Orissa into British dominion in 1803, the colonizers sought to draw legitimacy for their rule by obtaining approval of Orissa's presiding deity and negotiating with his earthly representative, the Khurda Rājā and the king of Orissa. One of the obvious sites which drew the attention of missionaries in Orissa was Puri and its presiding deity, Jagganath. For the missionaries, however, "Juggernaut" as the "Moloch of Hindoostan" was equally important as he stood as the greatest obstacle to the progress of Christianity.

Missionaries turned critical to the protective policy of the Company towards Hindu institutions as well as collection of revenue from Hindu temples and pilgrim tax after their entry into the Company domain in 1813. They believed that such policy lent legitimacy to idolatry which could hardly be endorsed by the civilized British rule. The pilgrim tax was rescinded in 1840 after a hard fought battle by the missionaries. Claudius Buchanan, a Company chaplian during his visit to Puri in 1806 depicted it as the "valley of death" which was truly comparable to "valley of Hinom" (Buchanan 1812, pp. 26-36). He depicted Puri as "the offensive effluvia of the town ... the squalid and ghastly appearance of the famished pilgrims" and a nasty place with people "of both sexes with little regard to concealment, sit down on the sands close to the town, in public view, and the sacred bulls walk around them and eat the ordure".

Similarly, Reverend Buckley described pilgrimage to "Juggernauth", "the hateful temple of Orissa's hideous idol" as destructive of life and "Pooree" as a "gigantic nuisance" from sanitary point of view (Smith 1868, part IV, pp. 156-58). ${ }^{12}$ Reiterating Buchanan's view that "there is no mercy in Moloch's kingdom”, he would refer to the cru-

\footnotetext{
${ }^{12}$ Buckley to Civil Asst Surgeon, Cuttack, 28 Nov. 1867, Home (Pub).164, 1 Jan. 1870, National Archives of India, New Delhi.
} 
elty with which the cholera patients were treated in Puri when they were turned out and left to "die in the street".

It is noteworthy that the missionary polemic on Jagganatha and Puri as "valley of death"; "enormity of superstition"; "Moloch of Hindoostan"; "obscenity and blood"; "squalid and famished pilgrims" and the linkages drawn for Puri with satī or with "misery, disease and death" not only impacted western discourse on Hinduism but continued to be recycled in the medical and official discussion as well (Buchanan 1812, pp. 26-36; Arnold 2006, p. 70; Nanda 2016, pp. 305-318). More so, the sanitary view of the colonial government came to be largely defined by the missionary perspective on Puri and Hinduism by providing it a gloss of its own scientific authority.

The initial health interventions by the colonial administration to control the inscrutable malady (Arnold 1993, p. 161) of cholera can be identified through the establishment of Puri pilgrim hospital (1836) in a climate of denunciatory missionary propaganda. However, the two seminal reports: (i) a report on cholera mortality by physicianMoreau De Jonnes (1831) (Arnold 1993, p. 162; Joseph 2001, pp. 211-213) $)^{13}$ and (ii) the report of International Sanitary Conference at Constantinople (1866) - which sought to implicate the temple of Jagannath as a site of epidemic cholera - justified special responsibility for medical interventions to address the disorder caused by the dreaded disease. Alongside these developments, the takeover of India by the crown (1858) and subsequent appointment of provincial sanitary commissioners, apart from the devastating $\mathrm{Na}$ Anka famine of coastal Orissa in 1866 contributed to the engaging focus of colonial government to cholera, sanitation and health policy interventions.

International Sanitary Conference maintained that Puri and pilgrimages specifically in India contributed to the cause of propagation of cholera epidemic. This spurred the Government of India to form a committee under the Sanitary Commissioner of Bengal, David B. Smith to report on the pilgrimage to Jagannath in 1868. In the aftermath of the famine of 1866 , the issue of pilgrimage

\footnotetext{
${ }^{13}$ Alexander Moreau De Jonnes, the French physician reported in 1836 that cholera affected one-tenth of population of British India and killed one-sixteenth based on a rather inflated figures of mortality of certain areas of Bengal and among the troops of East India Company over a period of 1817-1831. Moreau was known for his contagionist argument that cholera was transmitted through trade and troop movement.
}

and sanitation had also become subjects of intense official debate. Smith's report while surveying the sanitary conditions of Puri unfailingly solicited the missionary views on these issues.

The Smith report touched upon the issue of sanitation not only from medical standpoint but significantly from perspectives of Hindu religion and culture (Smith 1868, part I, pp. 1-41). While calling for the need to understand sanitary engineering with the help of chemistry, hygiene, and medicine, his account equally articulated moral and religious viewpoints. Agreeing mostly with the Inspector General of Jails for Bengal, Dr. Mount's series of recommendations on the sanitary reform of Puri in 185556 , Smith recommended measures relating to scavenging and prohibition of nuisance for cleansing the town, engagement of sanitary police, prevention of overcrowding, improvement of drainage system and assessing the quality of potable water (Smith 1868, part 1, pp. 1-41). He stressed on the importance of recruiting a large permanent conservancy staff, use of disinfectants, latrine and clean drinking water, regulation of lodging houses, deflection of pilgrims route outside the town, use of provisions of Indian Penal code in regulation of sale of unwholesome mahāprasād (holy food). He favoured the idea of "separate cholera hospital at Poorree" and temporary cholera sheds to isolate the sick. He considered medical patrol, compilation of medical statistics on cholera, sickness and death from all causes, establishment of hospitals, and dispensaries along pilgrim routes as means for monitoring public health. Creation of public funds for regular cleaning of tanks and wells and establishment of a medical school at Cuttack to train doctors and compounders who could cater to medical needs on pilgrim routes were also recommended by him.

However, his report delineated the linkages of repugnant religious and social practices of the Oriya people to the spread of disease in the "valley of death". The report sought to map the landscape of Puri as "dark, dirty, dismal and pest-house like lodging houses... tanks emitting noxious gases; persistent odor of decomposed fecal matter and lack of oxygen; religious congregation and the sway of famine, cholera and dysentery." He related the cause of the cachectic state of a large proportion of Ooriyas, "having their blood and secretions deteriorated... with enlarged spleens, feeble and flabby muscles" to the state of destitution and poverty in which people "eat what- 
ever they can get however innutrious it may be..." (Smith, 1868, part I, pp. 99-100). He furnished a long list of diseases ranging from "gastric and intestinal affections, glandular enlargements, rheumatism, cutaneous diseases like scabies, impetigo, herpes, fevers, dysentery and epidemic cholera and smallpox" which accounted for an exceptional high death rate. He also ascribed the causes for the prevalence of "cutaneous diseases like ulcers, sloughing sores, diarrhea and other grave disorders" to habit of people to eat stale fish. He linked the "sickness and mortality of the areas" to "physical well-being of the nation (based on) fatigue, fasting, penance, and pain leading to feasting, dissipation, sensual excesses, reckless orgies, and great mental excitement”. He further depicted "Oriyas" as "simple people with a mere competence (with) marvelous mental inertia ... more apathetic and sluggish than positively stupid" (Smith 1868, part I, p. 92). Encoding a subtle critique of Hindu beliefs and practices, his sanitary report including his views on cholera exemplified a clear condemnation of Hindu religious beliefs, and, a vocal indictment of a culture and race.

Smith considered pilgrim sanitary tax as politically inexpedient and cautioned strongly against any such imposition (Smith 1868, part I, pp. 144-152). He observed that, "better, in my opinion, would it be that India should be devastated by cholera than subject to religious persecution". Instead, he viewed that the "Rajah, the purharries (cooks) and the pundhas (priests)" should be taxed as they accumulate a lot of wealth (spoils) from the pilgrims who visit Puri.

He recommended instead a series of measures to improve the sanitary conditions of Puri namely, (a) by addressing issues of abuses of pilgrimage without directly interfering with it; (b) supervision over lodging house keepers and sale of mahāprasād; engaging the services of a European doctor; (d) establishment of a dispensary at Piplee; (e) gazettee notification about occurrence of cholera and attendant death of people; (f) strict sanitary measures at the shrine; (f) creation of "Pooree Sanitary Fund" to collect voluntary subscriptions from wealthy native gentlemen visiting Puri "to mitigate the evils of pilgrimage"; (g) large annual government grant for the "systematic alleviation of physical miseries" affecting not only "Pooree alone or even Orissa... (but) the general population of India”.

The missionary condemnation of Puri and its pilgrims was further reinforced in Hunter's historical account of
Orissa written in 1872. Sharing such concerns along with the views of International Sanitary Conference in 1866 which attributed the causes of cholera epidemic significantly to Hindu and Muslim pilgrimage, he held Orissa as the lurking site from where "man's most deadly enemies was ever ready" to pounce upon the world. ${ }^{14} \mathrm{He}$ convincingly quoted British surgeon $\mathrm{C}$. McNamara's finding that, "every outbreak of the disease beyond the confines of British India may be traced back to Hindustan". His account echoed expressively a morbid fear of Asiatic cholera by countries beyond the Himalayas when he observed, "as America, Europe and the greater part of Asia may justly blame India for all they have suffered from cholera”. In equal measure, he argued, Puri could be blamed by India "for subjecting annually whole provinces to the chance of epidemic" (Hunter 1872, pp. 165-166). He further cautioned that "over-crowded, pest-hunted dens around Jagannath" in Puri may turn out to be centres of radiation of the disease into "the great manufacturing towns of France and England" (Hunter 1872, p. 166).

Hunter's endorsement to the idea of Asiatic cholera- as also an "Asiatic scourge" - a view propounded by Surgeon C. McNamara and his contention of Europe's right to demand preventive measures by the Indian Government against cholera sought to highlight the "ancient and abiding" fear of Europe against the "Asiatic hordes" - the cholera carrying pilgrims of Puri. However, he warned against the idea of total prohibition of pilgrimage as it would be deemed as "a great national wrong" by the 150 million of British subjects.

Despite such endorsement to a contagionist basis of cholera through its identification with pilgrimage in both medical and official establishment, the government did not favour measures in the form of quarantine or some kind of pilgrim tax for fear of religious or political backlash. Besides it was also acknowledged that any form of stricter control and a series of effective sanitary measures involved an expensive health programme and as such would require considerable resources on the part of colonial government. Hunter thus laconically summed up the crisis facing sanitary enterprise in India as well as Puri as "medical men are driven from one project to

\footnotetext{
${ }^{14}$ Hunter's chilling conclusion to his chapter on Pilgrims of Jagannath reads: "the squalid pilgrim army of Jagannath with its rags and hair and skin freighted with vermin and impregnated with infection, may any year slay thousands of the most talented and beautiful of our age in Vienna, London, or Washington".
} 
another, as each is found to be either too costly to Government; or too opposed to the superstitions of the native" (Hunter 1872, p. 165). Puri for Hunter thus exhibited a typical case exemplifying the challenges pitted against sanitary science in India. ${ }^{15}$

The contagionist stance on cholera and the colonial discourse on Hindu pilgrimage, mentioned in the accounts of Smith and Hunter were invoked in the official public health reports of Orissa in the 20th century, when new research studies on Puri's connection to cholera received official impetus. For instance, both O'Malley and P. T. Mansfield began their accounts on cholera in Puri with graphic quote from Hunter's account on the issue (O’Malley 1908, p. 129; Mansfield 1929, p. 142; O'Malley 1933). These accounts pointed to the formation of a vicious circle in which Puri stood to be infected by pilgrims and then districts in turn got affected by Puri. Similarly, Major Greig, who headed a special research study on cholera at Puri around 1913 noted with concern that cholera carrier in the form of unrecognized and wandering cases suffering from bad livelihood could potentially spread the seeds of the disease broadcast. ${ }^{16}$ Austen Smith, the Inspector General of Civil Hospitals, Bihar and Orissa dubbed the disease of cholera in 1921 as an imperial one in view of the potential of the cholera infected pilgrims of Puri spreading the disease all over India.

Against the backdrop of the official perception of the disease, the local government decided to raise new source of revenue by taxing the pandās of Puri through enactment of Puri Lodging House Act in 1871. The pandās who were bitterly targeted in the official reports as "pilgrim hunters" were made to pay for sanitation for renting their houses to the pilgrims (UD, 4 February, 1871 and 27 May, 1871). But the implementation of the act entailed serious difficulties and turned out to be a source of oppression for the pilgrims. Utkal Dipika joined the issue criticizing the apathy of the government to utilize the revenue earned through such taxation for pilgrim welfare including treatment of cholera (UD, 25 July, 1874 and 10 March, 1877)

\footnotetext{
${ }^{15}$ Hunter would note thus, "In no country does the public health more urgently demand the aid of that science. But the ignorance, prejudices, and suspicions of the people on the one hand, and the vast demands upon the revenue for more visibly and perhaps more urgently needed public works on the other do not leave sanitation a chance".

${ }^{16}$ B \& O Doc.33192. Sanitary Report of Bihar and Orissa for 1912 and Vaccination Return 1912-13, OSA.
}

\section{Towards a pathological province}

The broader political implications of the disease and its financial prospects continued to plague the government's adherence to a policy of indecisive and cautious interventionism. This largely shaped foundational basis of Odisha as a "pathological province" from the standpoint of public health in the 20th century. ${ }^{17}$ The continued uncertainty about the nature of the disease and mode of its transmission conduced to promote a policy of low-key intervention within the colonial bureaucracy and medical establishment despite the official endorsement to the theory of contagion by the turn of the century.

The vernacular press exhibiting the views of intelligentsia remained critical of the apathetic attitude of the authorities in providing treatment to cholera affected people right since 19th century. It stressed on the need to disseminate popular awareness about the curative aspects of the disease based on modern medicine as well as supply of medicine through police stations and newspaper advertisements (UD, 23 March, 1873). It also focused on issues like monitoring the movement of pilgrims, and crowd near ferry ghăts, ensuring hygienic standard of inns along pilgrim routes as well as standard sanitary measures like cleaning of canals and drainage of rain water as measures to fight cholera epidemic (UD, 18 September, 1875; 16 July 1881).

It also highlighted the role of contagion spreading cholera epidemic. The reasons for the formidable prevalence of disorder like cholera and other diseases of organs and digestive system among the poor people of Cuttack was attributed to "the effects of constitutional changes... more than climatic factors". The changed dietary practices comprising of rice, salt and coarse vegetables among the middle class and urban population were induced by the 1866 famine in view of rising prices of commodities.

\footnotetext{
${ }^{17}$ Mansfield Secretary (reforms) to the Govt. of Bihar and Orissa, during the course of the debate (1934-35) over the recommendations of Orissa Administration Committee for the upcoming separate province of Orissa referred to the Inspector of General, civil hospitals of Bihar and Orissa, Colonel Buckley's opinion of Orissa as the most pathological province in India in view of its unhealthy climate as well as prevalence of diseases like kala-azar, leprosy, cholera, malaria, filariosis and smallpox. See, File no. F.79/35/ Recommendations made in the Orissa Administration Committee Report in respect of Public Health, Hospitals and Jails, Govt. of India (Home Department), National Archives of India (NAI); File no.22-4/35-H, Orissa Administration Committee Recommendations in respect of Public Health, NAI.
} 
It accounted for the physical debility of the people of Cuttack and the consequent exposure to infection in the postfamine years (UD, 3 August, 1878). Congregation of pilgrims during festivals was the source of the disease in Puri which consequently spread to the rural areas. It was observed that cholera which was confined to the hot summer season came to be attributed to the people instead (UD, 24 February 1877). The pollution of river sources due to dumping of corpses of cholera patients into the water was a major factor for the germination and spread of the disease in the rural areas (UD, 30 September, 1884).

Alongside such opinions, echoes of cultural orientations of people/race, and environmentalism focusing on the non-contagionist aspect of the disease continued to be invoked in several sanitary reports. For instance, a sanitary report of 1913 speculated that the unusually high mortality occurring from dysentery and diarrhoea in Puri, Balasore and Sambalpur districts could be traced to food habits of Oriyas. It was based on Major Fry's observations on the tribal people of Ranchi who were believed to be suffering from dysentery due to their habit of eating roots after exhausting their store of rice quickly. ${ }^{18}$ Similarly, W. C. Ross, I. M. S., the director of public health in 1924 opined that climatic conditions along with host of other contributory factors produced the malady (O’Malley 1929, p. 143). The cholera as a disease of the poor continued to be voiced in public health reports. As late as a report of 1939 cited the co-relation of lowered vitality and derangement of intestines among the lower classes with their consumption of unwholesome and bad food under flood conditions. ${ }^{19}$

However, despite persisting polemic on cholera, Puri and pilgrimage, a significant decline in cholera mortality was acknowledged in official report during three decades since 1880s. The reason for this was attributed to an interventionist strategy based on sanitation, drainage, segregation and inoculation. The memory of death of thousands of people due to cholera during the Nabakalebara (renewal of bodies of the deities of Jagannath temple) festival of 1892 was so haunting that the colonial authorities had to put in place temporary arrangements for accommodation, water supply and conservancy in the subsequent Nabakalebara festival of 1912. The measures included encampment of pilgrims in temporary bamboo mat sheds

\footnotetext{
${ }^{18}$ B \& O Doc.33192. Annual Sanitary Report of Bihar and Orissa for 1912 and Vaccination Return 1912-13,OSA.

${ }^{19}$ OR. Doc.7381. Cholera epidemic in villages of Orissa, OSA.
}

near railway station, use of moveable trench latrines, placing of guards over sacred tanks to prevent bathers drinking the water; and pumping of waters from semi-protected wells into overhead cisterns located in different parts of the town, provision for collection of earliest information on cholera cases and their immediate hospitalization, disinfection of the house of such patients; extension of beds and furnishing the cholera hospital with modern appliances. ${ }^{20}$ Further, piped water supply from tube wells was introduced in Puri from $1935 .^{21}$ It is noteworthy that railways paradoxically, emerged as a facilitator for lessening spread of contagion as it rapidly cleared out passengers in certain places while it proved to be a new and common source of infection due to huge pilgrim movement into Puri.

Thus the growing official concern to deal with cholera epidemic led to free supply of cholera vaccine and cholera pills from 1936 during melās (religious congregations) at district levels. $^{22}$ Similarly, the war time shortage of bleaching powder resulted in adoption of new preventive methods like use of boiled water for drinking, using coal tar and freshly slacked lime for purposes of disinfection. ${ }^{23}$ However, strategies of immunization through anticholera inoculation as well as use of boiled water and uncontaminated food continued to be voiced at the lower rung of health bureaucracy till about late 1930s. ${ }^{24}$

It merits emphasis that the financial considerations assumed overriding concerns for the administration when it was an issue to deal with cholera epidemic. A demand for engagement of one health staff in each affected village to treat cholera cases was considered improbable in view of the epidemic nature of the disease and fund constraints. The demand was dismissively rejected by referring to public health's focus on preventive measures as contrasted to

\footnotetext{
${ }^{20}$ B \& O Doc. 33192. Annual Sanitary Report of Bihar and Orissa for 1912 and Vaccination Return 1912-13; From Sanitary Commisioner, Bihar and Orissa, Lieutnant-Col. E.C. Hare I.M.S., to The Secretary to the Govt. of Bihar and Orissa, Municipal Department, 26 April, 1913, OSA.

${ }^{21}$ OR. Doc. 7137. Note by Director Public Health regarding some points about Public Health Organisation 19/3/1936, OSA.

${ }^{22} \mathrm{Ibid}$

${ }^{23}$ OR. Doc. 7360. Annual Public Health Report for 1939 and Annual Vaccination Report for 1939-40 by Lt. Col. G. Verghese, I. M. S., Director of Health and Inspector-General of Prisons, 19 September, 1942, OSA.

${ }^{24}$ OR. Doc. 7381. Cholera in Jagatsingpur Thana; Report by Asst. Director Public Health, B. Nayak: 18.11.39, OSA.
} 
curative orientation. ${ }^{25}$ The district boards palpably often remained hard pressed to organize relief for the poor in the rural areas in the face of cholera epidemic. A petition addressed to Biswanath Dash, the Prime Minister of the provincial government in 1939, resented the half-hearted measures of the district board in connection with wholesale inoculation of the village. It urged the congress ministry to distribute taccavi loan and relief money along with medicines and saline injections for the half-clad and halfstarved people. $^{26}$

Similarly, the issue of excavation and multiplication of tanks for drinking water supply sparked off a debate around 1941-42 even though the need for filtered and piped water supply had been stressed as early as $1921 .^{27}$ Dubbing the tanks as pitfalls of death for causing yearly epidemic of cholera due to their contaminated water source and thus menace to public health, the director of health considered the excavation and multiplication of tanks as an absolute futility of spending money. The local government's attempt to tighten its control over excavation and re-excavation of tanks was opposed by the local board. The latter argued that tanks were the only solution of improving the insanitary condition of a locality and that sinking of wells was impossibility. The government finally had to concede to the view of the district board that tanks could not be altogether excluded and resolved in favour of keeping tanks in sanitary condition in the interest of people. ${ }^{28}$ The debate surprisingly did not broach the issue of filtered or piped water nor did the government show any inclination for the proposal of deep masonry sanitary wells as mooted by the director of health. The sanitary measures of the colonial state, evidently thus, continued to be weighed against financial expediency late into the early decades of 20 th century.

As late as 1940s, the endemicity of cholera in the coastal districts fuelled by pilgrim traffic, floods and inadequate

\footnotetext{
${ }^{25}$ OR. Doc.7253. Report of Health Officer, District Board Cuttack, OSA.

${ }^{26}$ OR. Doc.7381. Epidemic in villages of Orissa: Petition from Secretary: Palli Seba Sangha regarding Cholera epidemic in the village and taccavi loan, 16 September 1939, OSA.

${ }^{27}$ OR. Doc. 28568. Notes on the Annual Returns of the Hospitals and Dispensaries in Bihar and Orissa, 1920; Report by Inspector General of Civil Hospitals, Bihar and Orissa H. Austen Smith; 3 March, 1921, Patna, OSA.

${ }^{28}$ OR. Doc. 28568 . Notes on the Annual Returns of the Hospitals and Dispensaries in Bihar and Orissa, 1920, OSA; Cholera epidemic in villages of Orissa, op.cit.
}

supply of wholesome drinking water were seen to be one of the greatest anxieties of a public health worker in Orissa. Such anxieties strikingly emanated from ignorance, superstition, insanitary habits and lack of civic responsibility on the part of the people. ${ }^{29}$ Similarly propaganda against scientific public health measures by quacks, popular ignorance with regard to elementary principles of health and hygiene were considered as formidable challenges facing the health worker in cholera work. ${ }^{30}$ Here as in the case of the insanitary habits of pilgrims, the popular ignorance and superstition were to be blamed.

\section{Bibliography}

[1] Arnold D. Colonizing the Body: State Medicine and Epidemic Disease in Nineteenth Century India, 125, University of California Press, Oxford University Press, Berkley and London, 1993.

[2] Arnold D. The Tropics and the Travelling Gaze: India, Landscape and Science 1800-1856, University of Washington Press, 2006.

[3] Behera K. C. and Dash D. C. (eds.). Fakir Mohan Granthabali, Part III, (Revised Edition), Grantha Mandir, Cuttack, 2009.

[4] Buchanan C. Christian Researches in Asia with Notices of the Translations of the Scriptures, London, 1812.

[5] Dash J. P. Puri: March 1866, Desha Kala Patra (Oriya), (4th edition), Friends Publishers, Cuttack, 2011.

[6] Das N. Atmajivani, Cuttack Students Stores, Cuttack, 1963.

[7] Elwin V. The Religion of an Indian Tribe, Oxford University Press, London, 1955.

[8] Guha R. Elementary Aspects of Peasant Insurgency, Duke University Press, 1999.

\footnotetext{
${ }^{29}$ OR. Doc. 7283. Annual Public Health Report for 1938 and Annual Vaccination Report for 1938-39, OSA; OR. Doc. 7360, Public Health Report for 1939 and Annual Vaccination Report for 1939-40, OSA. ${ }^{30}$ OR. Doc. 367. Improvement of Public Health/ Public Health Conference held at Ganjam, OSA.
} 
[9] Hunter W. W. Orissa or the Vicissitudes of an Indian Province under Native and British rule, vol. I, London, 1872.

[10] Johnson James. The Influence of Tropical Climates, More Especially the Climate of India, on European Constitutions, Stockdale, London, 1813.

[11] Joseph G. M. (ed.). Reclaiming the Political in Latin American History: Essays from the North, Duke University Press, 2001.

[12] Mansfield P. T. (ed.). Bihar and Orissa District Gazetteers, Puri, Patna, 1929.

[13] McNamara N. C. A Treatise on Asiatic Cholera, Churchill, 1870.

[14] Mohanty K. C. Shasti, (14th edition), Friends Publishers, Cuttack, 1994.

[15] Nanda C. P. Disciplining a 'Pathological Province? Epidemic Disease and Health Interventions in Colonial Orissa, Sectional President's Address, Indian History Congress Proceedings, Delhi, 2016.

[16] O’Malley L. S. S. (ed.) Bengal District Gazetteers, Angul District, The Bengal Secretariat Book Depot, Calcutta, 1908.

[17] O’Malley L. S. S. (ed.) Bengal District Gazetteers, Puri District, The Bengal Secretariat Book Depot, Calcutta, 1908.

[18] O’Malley L. S. S. (ed.). Bengal District Gazetteers, Balasore District, The Bengal Secretariat Book Depot, Calcutta, 1911.

[19] O’Malley L. S. S. (ed.). Bihar and Orissa District Gazetteers, Puri, Patna, 1929.

[20] O’Malley L. S. S. (ed.) Bihar and Orissa District Gazetteers, Cuttack, Government Printing, Patna, 1933.

[21] O’Malley L. S. S. (ed.). Bihar and Orissa District Gazetteers, 2nd edition, E. R. J. R. Cousin; Cuttack District, Government Printing, Patna, 1933.
[22] Pati B. Ordering Disorder in a Holy City: Colonial Health Interventions in Puri during the Ninteenth Century, In Biswamoy Pati and Mark Harrison (eds.) Health, Medicine and Empire: Perspectives on Colonial India, Orient Longman, New Delhi, 2001.

[23] Sen S. Indian cholera: a myth, Indian Journal of History of Science, 47.3 (2012): 345-374.

[24] Smith D. B. A Report on Pilgrimage to Juggernauth in 1868 with a Narrative of a Tour through Orissa, A Sanitary Survey of Pooree, and Notes on cholera, Inland Quarantine, a Pilgrim Sanitary tax, Pooree Lodging House Bill (Part I, II, III, IV), Calcutta Central Press, Calcutta, 1868. 